\section{The onset of peace}

\section{Ron Smith and Ali Tasiran}

$\mathrm{D}$ uring the twentieth century, following the work of the Quaker mathematical cientist Lewis F. Richardson, there developed a minor industry devoted to counting wars with the aim to identify statistical patterns in war data. Today's databases, such as the Correlates of War (COW) and the Uppsala Conflict Data Program (UCDP), have grown in detail and coverage and are widely analyzed. The statistical use of these large and complex datasets involves a variety of assumptions, not always appreciated by those unfamiliar with the techniques used. In this article, we examine the UCDP dataset on the duration of war and provide an exposition of the nature of the data, the transformations involved, and the statistical techniques used to quantify the dynamics of war. In particular, we are interested in determinants that may herald the onset of peace.

A recent review of 30 datasets on conflict shows significant differences between the two main sources, UCDP and COW, in the list of interstate wars, presumably the least difficult type of war to code. ${ }^{1}$ Thus, the statistical focus on war and peace has not been uncontroversial and many have questioned whether it is possible to quantify such complex social phenomena. They argue that the coding rules used to turn inherently qualitative phenomena into quantitative measures will inevitably be arbitrary and that this makes them unsuitable for quantitative modeling. Others have argued that only the most sophisticated quantitative techniques will distinguish the signal from the noise in such data. ${ }^{2}$

A recent critique of quantitative studies identifies a variety of problems. ${ }^{3}$ Indeed, it can be difficult to distinguish war from other types of violent conflict. One famous scholar, namely Lewis F. Richardson himself, avoided the distinction altogether and instead examined at what he called the Statistics of Deadly Quarrels, whether they might be counted as wars or not. ${ }^{4}$ With one prominent recent exception, his lead has not generally been followed, and rules have been developed to distinguish war from other types of violence, for instance criminal violence. Whether this distinction is appropriate is a matter of judgment as violent death rates can be much higher in countries at peace, particularly in Latin America, than in countries at war. ${ }^{5}$ One definitional characteristic used to distinguish war from other deadly quarrels is that a government must be directly involved in a conflict about a political or territorial issue. This still leaves difficulties such as distinguishing whether or not the conflict is between government and an organized criminal group or a politically motivated group, how to treat conflicts that take place in territories without a government, such as Somalia as from the 1990s, and how to treat multiple simultaneous conflicts: For example, should the various conflicts during World War II, or more recently in Sudan, be regarded as different conflicts or as part of the same conflict? Even when agreeing on war, coders may not agree on when it started and why, when it ended, how many died, and whether people died in battle or not. Disagreement along these and other dimensions results in differences across datasets.

Despite coding differences that may amount to measurement errors, quantitative data can capture important features of a complex qualitative social reality. It is useful to examine whether or not systematic patterns in the quantitative data on war may be found. Indeed, the large number of conflicts themselves may make it easier to identify systematic patterns, if any, because there is a probability (although no certainty) that measurement errors and conflict specific factors may cancel out. If this is the case, then so-called large- $n$ analysis may allow one to identify common patterns-those underlying all wars - that may not be obvious when one conducts case studies of individual conflicts, as these are swamped by the effects of specific factors.

The UCDP dataset that we use records, since the end of World War II, a total of 235 armed conflicts, involving 123 countries in 149 locations. Many countries had multiple spells of conflict of varying durations. In 2007, our last data year, there were 35 ongoing armed conflicts in 22 locations. Historically speaking, this is a relatively low number but the continuous decline seen since the early 1990s now seems to have ceased. ${ }^{6}$ Despite (or because of) the arrest in the decline of war, scholars continue to study the potential determinants of violent conflict, focusing for instance on the interdependence and duration of militarized conflict, the transnational dimensions of civil war, and the role of enduring internal rivalries in civil wars. ${ }^{7}$

Our aim is to examine the methods used to analyze war dynamics, variables such as the number of spells of war, their duration, and how they end, for example by victory or by cease-fire, and to learn whether they are influenced by the nature and/or source of the conflict (nature: e.g., an international dimension; source: e.g., an incompatibility over territory or government). Data on each of these variables are available in the UCDP dataset. The techniques we use are multispell transitions with a semiparametric Cox-type proportional hazard duration model and a fully parametric log-logistic duration model.

The next section characterizes Richardson's ideas, followed by a discussion of methodological issues. Then follow a presentation of the data, a discussion of the estimation strategy, and the reporting of the results of our semiparametric, Cox-type proportional hazard estimates and of the parametric log-logistic estimates which treat war spells according to spell order and outcomes. The final section concludes the article, followed by endnotes, references, and a technical appendix. 


\section{Richardson's ideas}

Richardson is one of two persons usually cited as founders of the systematic study of the causes of war. (Quincy Wright is the other.) He favored quantitative study: "There are many anti-war societies, but they are concerned with propaganda, not research. There is a wide public interest in the subject provided it is expressed in bold rhetoric, but not if it is quantitative scientific study involving statistics and mathematics.” A student of the great statistician Karl Pearson, Richardson accepted Pearson's contention that "popular beliefs ought to be tested by statistics." His quest led him to search for data on "deadly quarrels [in] the whole world since the beginning of A.D. 1820 ” about "belligerents."

Richardson treated war as a species of "deadly quarrels.” By this he meant any quarrel which caused death to humans. The term thus includes murder, banditry, mutiny, insurrection, and war small and large but excludes accidents and calamities such as earthquakes and tornadoes. Deaths by famine and disease are included if they were the immediate result of a quarrel, but not otherwise. In puzzling cases, the legal criterion of "malice aforethought” was taken as a guide.

Richardson defines "the magnitude of a quarrel [as] the logarithm to the base ten of the number of people who died because of that quarrel.” He finds that the onset of the number of wars per year followed a Poisson distribution, as did the onset of peace. Stars in space, raisins in a cake, wrong-number calls per day received per telephone, deaths per cavalry regiment per year from horse kicks-all of these show empirical distributions that closely fit the theoretical Poisson distribution of rare events. The Poisson patterns found by Richardson are confirmed by Wilkinson (1980).

Richardson noted that a "the larger, the fewer" maxim describes his fatal quarrels data. Fitting several log-log linear functions of varying generality, complexity, and utility, he found that in all of them the number of quarrels of a given magnitude diminished as their magnitude rose. This approximate power law distribution between frequency and size of conflict, with size measured in number of deaths or casualties, has been replicated for many subsequent conflicts. One study, published in 2009, presents data for nine recent insurgencies where the relationship between event size, as measured by casualties, and event frequency follows power laws. Insurgencies have exponents close to 2.5, whereas for conventional wars the exponent is rather lower, at around 1.7. The Poisson distribution for war onset, the power law relationship between size and frequency, and the democratic peace hypothesis (that democracies tend not to fight each other) are examples of statistical regularities, or commonalities, that the analysis of large datasets can reveal. ${ }^{9}$

\section{Survey of statistical issues in quantitative modeling}

A large literature exists on measuring the duration of war, often written as $d_{i j}$, the length of war $i$ in country $j .{ }^{10}$ Without attributing particular methods or approaches to particular authors, our discussion here surveys the modeling issues.

Unlike war termination, war onset is roughly constant at one to two percent of all countries in the international system per year. It follows that the number of wars in progress at any one point in time then largely reflects their duration. As war onset is difficult to predict, reducing the number of wars may be done more effectively by actions that speed the onset of peace. Believed to be caused by different things, it is common practice to separate the questions of what causes wars to start and of what causes them to continue once they have started. But one pair of authors note that this is a testable assumption, and they estimate a model that suggests that both onset and continuation reflect similar factors. ${ }^{11}$ The dependent variable in their analysis is simply whether there was a war in a particular year (a binary "yes” or "no" variable). In contrast, we look at duration, measured in days, which is a continuous variable.

As mentioned, measuring wars is difficult enough, depending on conventions for coding them; measuring their duration is more difficult since there is often doubt about exactly when wars begin and end. In particular, many countries suffer multiple spells of war. There may be a period of intense conflict, a period of low activity, and then renewed, intense conflict. Whether this is coded as two short wars or one long war has a major impact on estimation. Coding war onset itself also matters, because wars before the start date of the data cannot be used to explain subsequent wars. Further, peace can come in various ways, from plain victory by one side, or from a formal peace agreement, which we abbreviate as "peace”, or by cease-fire, or because the fighting just subsides.

The most common form of duration model are hazard models, the "hazard" being the rate of peace breaking out at a particular time, $d$, given that war continued up to then. (Technical details of such models are presented in Appendix A.) There is a baseline hazard, which shows how the rate (or "risk") of achieving peace moves over time. This risk is shifted by covariates such as external interventions and heterogeneity among the cases in the dataset. (This heterogeneity is usually unmeasured, or "unobserved" in statistical language, meaning that it is not explicitly coded in the dataset and results in being tucked away in the statistical model's degree of error.) The baseline hazard may be parametric_-following a particular specified shape-or nonparametric, completely free to move over time.

There is an issue as to whether there should be a common model for all wars or separate models for different types of war: small wars versus large wars, or interstate wars versus intrastate wars. If one pools the data, one treats wars as homogeneous, except to the extent that the covariates include indicators for different types of war. 
But if one partitions the data into wars of different types, one allows for heterogeneity in the form of the baseline hazard and the effect of the covariates, which may be plausible. For example, external intervention may have different effects on internal wars than on interstate wars. However, wars are comparatively rare events, so as one partitions the data, smaller samples result, making statistical estimation more difficult.

Various procedures are used to estimate the baseline hazard. Nonparametric procedures, which do not allow for covariates, involve graphing the empirical survival or hazard function, perhaps separately for different types of war. Semiparametric procedures, most commonly the Cox-type proportional hazards regression, allow for a completely flexible baseline hazard and measure the effect of the covariates. Again, one can allow the hazard function to differ for different types of wars. Parametric models specify a particular mathematical representation (functional form) for the baseline hazard, the simplest being the exponential function which depends on only one parameter - the exponent of the function-and has a constant probability or "hazard". Distributions with two parameters include the Weibull, log-normal, and log-logistic functions. The shape of the baseline hazard may be captured by binary variables, assuming a constant hazard over particular time intervals, or may be interacted with a parametric form, such as piecewise exponential. It is known that if the functional form accurately describes the duration dependence, parametric forms are more efficient: They use the available data more effectively.

The duration of war seems to depend of the way war ended: by victory, cease-fire, peace, or exhaustion. There is a circularity or information issue here-while war is in progress one does not know how it will end, and how it will end may depend on duration — so that disaggregating wars by how they ended raises statistical difficulties. Procedures to handle ending include competing-risks frameworks or modeling the type of termination directly with a multinomial choice model. The competing risks framework treats wars that do not end during the sample period as being censored.

Many countries have had multiple spells of war and characteristics of a priorperiod war may influence the duration of a current-period war. This so-called state dependence arising from multiple wars is handled in various ways. A simple method is to include years of peace and number of prior wars as covariates, but one may also want to include other characteristics of prior wars, such as how they ended.

The covariates - the relevant variables that change the chance of war ending-are usually chosen on the basis of some theory of war. There are many theories of war emphasizing motives such as greed or grievance, the feasibility of conflict, or the credibility of commitments to conflict alternative. Thus, a large number of possible covariates have been used in the literature. One must also choose the functional form for the covariates. These choices include whether to use the change, level, or cumulative sum of the variable, using logarithms or other data transformations, or using flexible functional forms like splines. For interstate wars, one must choose how to model the way the covariates of the multiple countries involved interact, although it is common to use dyad data and simply consider pairs of countries. One must also consider endogeneity issues, since some of the covariates may be influenced by the duration of the conflict. This is sometimes dealt with by using covariates taken from before a conflict began, but in countries with multiple conflicts there is likely to be correlation with earlier conflicts.

Typically the covariates fall into the following categories. Economic and social characteristics of the country include per capita income, income inequality, a measure of size such as population, trade flows, education, ethnic or religious divisions, and demographic features such as fertility, life expectancy, infant mortality, and proportions of the population in particular groups such as young men. Geographic characteristics of the country include location, by continent, latitude, access to the sea, number and nature of the neighbors (as war can be contagious), and forests, mountains (perhaps making insurgency easier). Nature of the state variables include democracy/autocracy, measures of state capacity such as tax revenues, bureaucratic quality, corruption, the size and effectiveness of the military, the state's integration into the international system through membership in international organizations. Source of conflict is often coded over government or territory. Economic or military intervention by third parties is coded in various ways. The intensity of war is measured in deaths per year and by characteristics of prior wars. Conflict financing includes state dependence on natural resource earnings, lootable resources available, commodity price shocks, illegal drug production, and diaspora support. Time itself may matter, as there seems to be a trend for wars to become shorter, although this may reflect changes in other covariates. To allow for this, one can introduce binary variables to stand for decades in the covariates. For interstate wars one would need to include the covariates for all the parties.

That there exist such a large number of possible covariates and that many of these are correlated with each other makes determining the causes of war and its duration and termination difficult. To illustrate the statistical procedures, we use a fairly short list of covariates.

\section{Data and estimation strategy}

Our focus is on duration of war before the onset of peace. In this section we describe the data, the transformations involved, and the specific statistical techniques used to quantify conflict dynamics. We have information on the following characteristics:

- The date a conflict started and ended and thus its duration, measured in days.

- The number of conflict spells and their order from first to last.

- The cause of conflict (territory or government)

- The nature of conflict (extrasystemic, interstate, internal, or internationalized internal).

- The region of conflict (Europe, Middle East, Asia, Africa, or the Americas).

- The intensity of conflict, measured as battle-related deaths between 25 and 999 
per year (minor) or 1,000 or more (major).

- The outcome of conflict (victory, peace agreement, cease-fire, no or low activity, or other).

There will be unobserved heterogeneity, that is, unmeasured factors which shorten or lengthen the duration of conflict.

Armed conflict is defined by UCDP as a contested incompatibility that concerns government or territory or both, where the use of arms forces between two parties results in at least 25 battle-related deaths in a year. Of the two parties, at least one has to be the government of a state. Conflicts are also classified by type as extrasystemic (an anticolonial or anti-imperialist war between one entity that is a member of an established set of states and one that is not), interstate (between two or more states), internal (between the government of a state and internal opposition), and internationalized internal (between the government of a state and one or more internal opposition groups, but with intervention from other states in the form of troops).

The dataset contains 123 countries over a 62-year period, 1946-2007, with a total of 235 armed conflicts recorded in 149 locations. This gives a total of 431 conflict spells (of which 35 were continuing at the end of 2007). Of these, 344 were minor wars and 87 were major wars. A conflict can change the level of severity from one year to the next. Table 1 presents data on the number of wars (major or minor) and the average length of war. Minor wars occur in almost twice as many locations and almost four time more frequently than do major wars, although the latter tend to be of shorter duration. The longest minor war was 48 years; the longest major war was 43 years. In Table 2, conflicts are ordered by the number of spells (repeat instances of the "same” war). The table also gives the mean spell duration (in days). Altogether, there are seven repeated conflict spells for a total of 431 spells. The first four spells are of approximately 4 years' length each, the fifth and sixth last about 2.5 years, and the seven-spell war-between India and Pakistan — adds up to almost 8 years of time. Table 3 gives the joint distribution of war size and source of conflict. The majority of the wars between 1946 and 2007 are internal, minor wars (260 of 431 wars). Purely internal plus internationalized internal wars are 346 in number. This is followed by interstate (63) and extra-systemic (22) wars. Extra-systemic wars are now far less common than used to be the case.

War termination is classified as (1) victory, (2) peace, (3) cease-fire, (4) no or low activity, and (5) other outcomes. Victory occurs when one side is either defeated or eliminated, or otherwise capitulates, surrenders, or makes a public announcement to that effect. Peace is an agreement — or the first in a series of agreements-concerned with the resolution of the incompatibility and signed, and/or publicly accepted, by all of the main actors in a conflict. Cease-fire is an agreement between all of the main actors in a conflict that terminates military operations. No or low activity conflicts are wars that idle or show very low activity. Other outcomes include cases where the conflict ceases without an observable victory or any type of agreement signed.
Fighting may in fact continue but at a level lower than needed to be included by UCDP as an active armed conflict. Alternatively, a party may withdraw from war for tactical reasons or due to leadership changes, or it may have decided on a nonviolent strategy or may have lost support from an ally. Table 4 provides data on the joint distribution of war size and type of termination.

Table 5 provides descriptive statistics, in two groups, for all 1,912 terminated spell years. The first group of variables is related to conflict length such as mean duration, spell number, censoring information, and lags of prior conflict duration. The second pertains to conflict outcomes, incompatibility reasons, conflict regions, conflict intensities, and types of conflicts. The distribution of durations is highly skewed by a few long conflicts. The median length is 457 days (about a year and a quarter); the mean length is 1,415 days (almost 4 years). There are up to seven conflicts in a country, and the average number of conflicts is 1.85, although some countries have no conflicts. Nineteen percent of conflicts are censored, meaning that the conflict was still ongoing at the end of the data period in 2007. Twenty-seven percent of all
Table 1: Wars by size, location, spells, and average duration in days

$\begin{array}{lcrl}\text { Conflicts } & \text { Locations } & \text { Spells } & \text { Average days } \\ & & & \\ \text { Minor } & 97 & 344 & 1,347 \\ \text { Major } & 52 & 87 & 1,686 \\ \text { Total } & 149 & 431 & \end{array}$

Table 2: Ordered spells, numbers of spells, and lengths of terminated wars

$\begin{array}{lrl}\begin{array}{l}\text { Ordered } \\ \text { spells }\end{array} & \begin{array}{l}\text { Number } \\ \text { of spells }\end{array} & \begin{array}{l}\text { Mean duration } \\ \text { (in days) }\end{array} \\ 1 & 235 & 1,434 \\ 2 & 99 & 1,480 \\ 3 & 54 & 1,326 \\ 4 & 21 & 1,559 \\ 5 & 15 & 937 \\ 6 & 6 & 863 \\ 7 & 1 & 2,887 \\ \text { Total } & 431 & \end{array}$

Table 3. Distribution of wars by size and source of conflict

$\begin{array}{lrrr}\text { War type } & \text { Minor } & \text { Major } & \text { Total } \\ & & & \\ \text { Extrasystemic } & 18 & 4 & 22 \\ \text { Interstate } & 40 & 23 & 63 \\ \text { Internal } & 260 & 49 & 309 \\ \text { Internationalized internal } & 26 & 11 & 37 \\ \text { Total } & 344 & 87 & 431\end{array}$




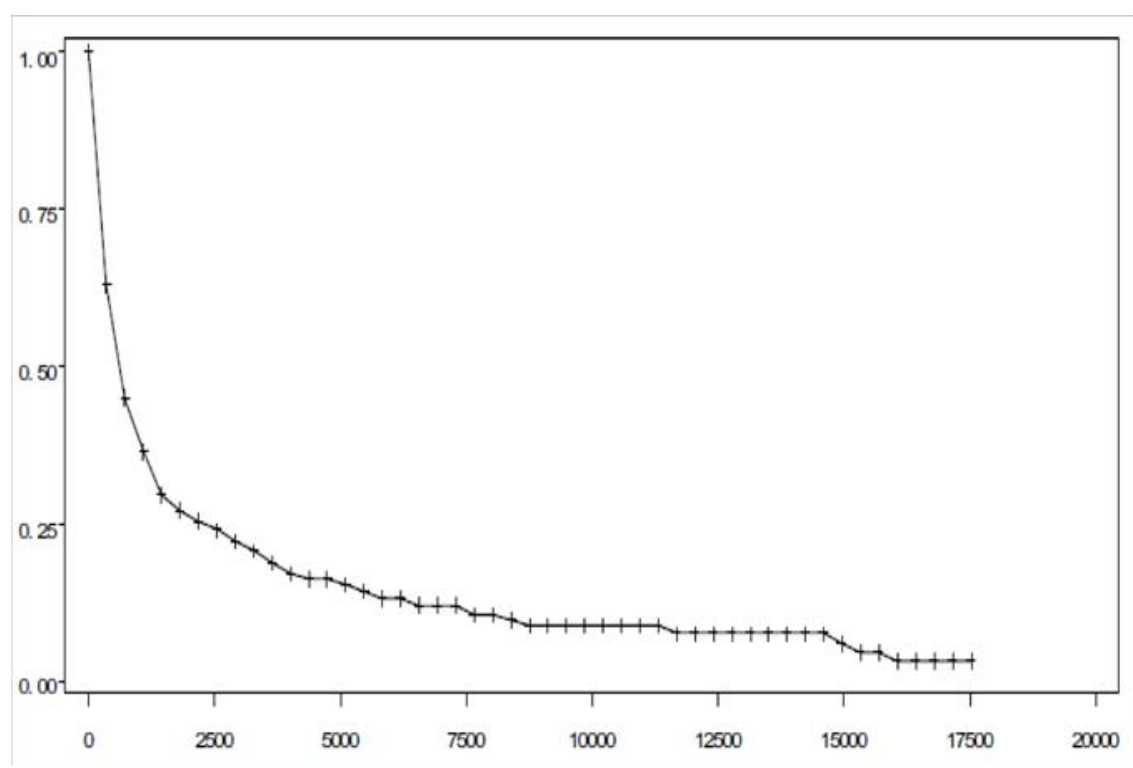

Figure 1: Survival function: Probability of conflict continuing, as a function of conflict duration (in days).

conflicts end with victory and twenty percent of conflicts end with a peace agreement. The proportion of territorial incompatibility is only 1 percent; the other 99 percent is for government incompatibility. The majority of spell years take place in Asia and Africa (33 percent each). The share of conflicts in the Middle East is 14 percent and is about 10 percent for the Americas and 9 percent for Europe. Minor wars have a larger share than major wars, 67 percent, and 80 percent of wars are internal: 71 percent purely internal and 9 percent internationalized internal.

Nonparametric estimation of survival and hazard functions

Conditional on a war having started in country $i$ in year $t$, we examine its duration, $\mathrm{d}_{\mathrm{it}}$, measured in days. Figure 1 gives the survival function for terminated war spells. The graph shows the proportion of wars that are still continuing as a function of the duration, in days, of the conflict. Almost 40 percent of all wars terminate within one year and almost 60 percent terminate within two years. ${ }^{12}$

Figure 2 shows the hazard rate (the "hazard" of peace) for all war terminations as a function of war duration, measured in days. This measures the "risk" of peace breaking out on a specific day, given that war continued until the prior day. During the first years of conflict, the rates are fairly high but they decline quickly. The sharp movements of the curve at the end of the war termination period are observed because 
(C) www.epsjournal.org.uk - Vol. 7, No. 1 (2012)

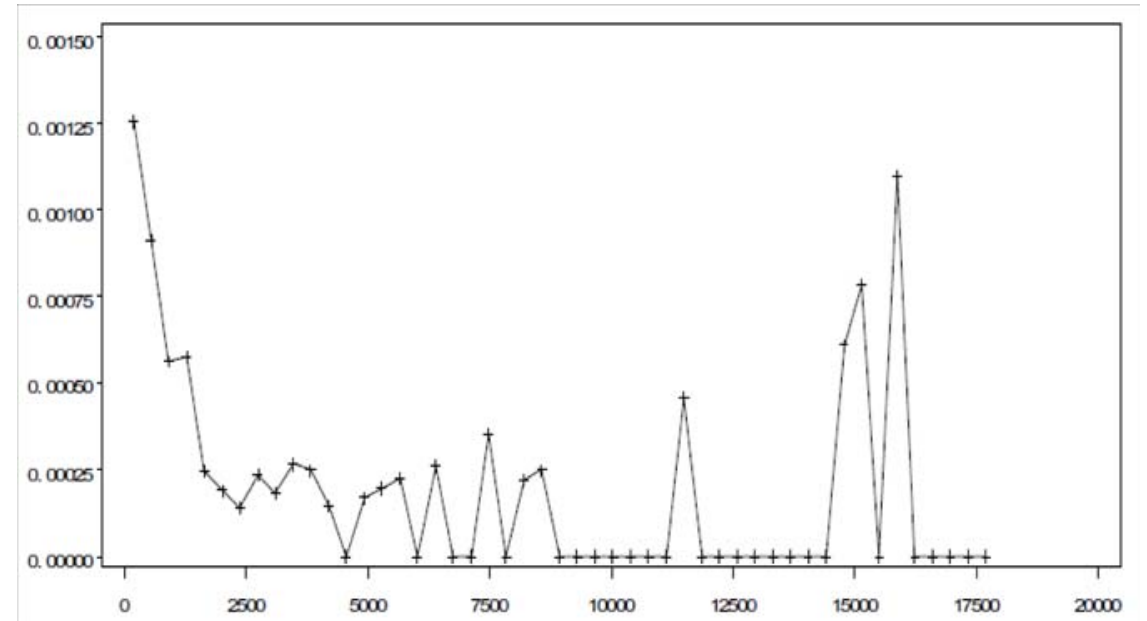

Figure 2: Hazard rates of peace as a function of war duration (in days).

few countries with continuing wars are left in the dataset and thus the "hazard" of peace in nonwar years must be zero.

Figure 3 shows the survival function for wars ending in a peace agreement, given the number of days the respective wars has been going on. The chances of a conflict ending with a peace agreement are above 75 percent during the first ten years or so, but then decline. Figure 4 gives the survival function for war spells ended by a ceasefire agreement. When directly comparing Figures 3 and 4 for any given day, say day 7,500 , the chances of conflict ending by cease-fire are generally higher than conflict ending by peace agreement.

\section{Estimates of semiparametric and parametric duration models}

The survival and hazard functions discussed thus far are unconditional — they do not allow for specific conflict characteristics-and nonparametric. In this section, we report estimates of a semiparametric Cox-type model where the baseline hazard is unrestricted and of parametric duration models where the baseline hazard is assumed to be a particular function of time, such as exponential, Weibull, Gompertz, log-normal, or log-logistic. We prefer log-logistic because this permits nonmonotonic hazard rates and both positive and negative time dependency. Unobserved heterogeneity causes a negative time dependency if it is not taken into account in the estimation (even as in our specific models this coefficient happened to be statistically insignificant in all cases).

We estimated a Cox-type proportional hazard model for different spells, having

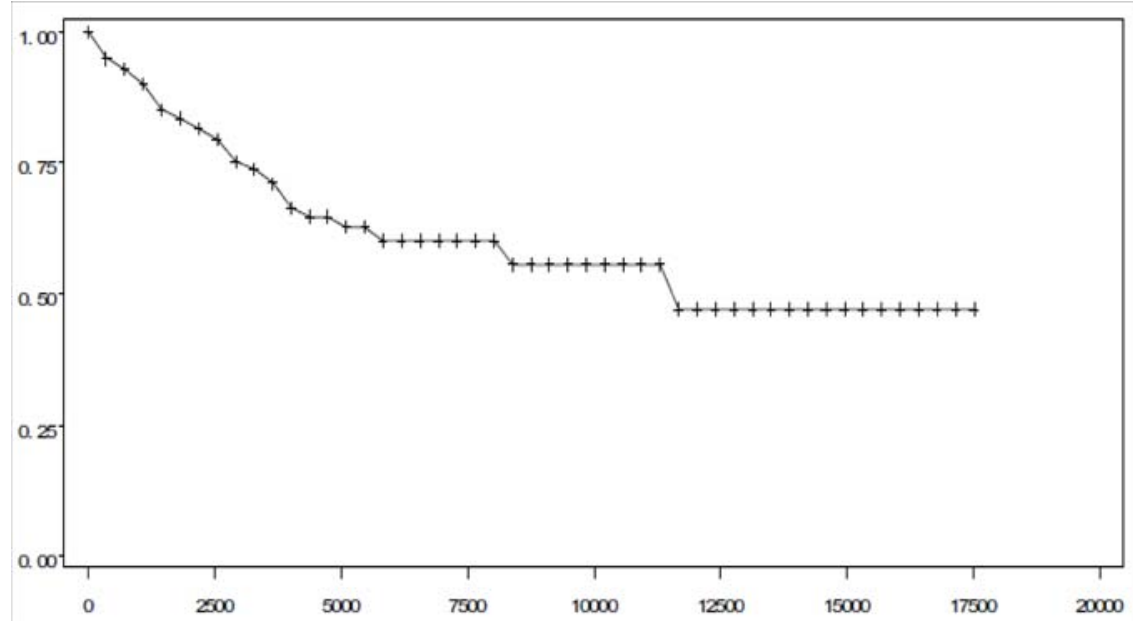

Figure 3: Survival function of conflicts ending with peace agreement.

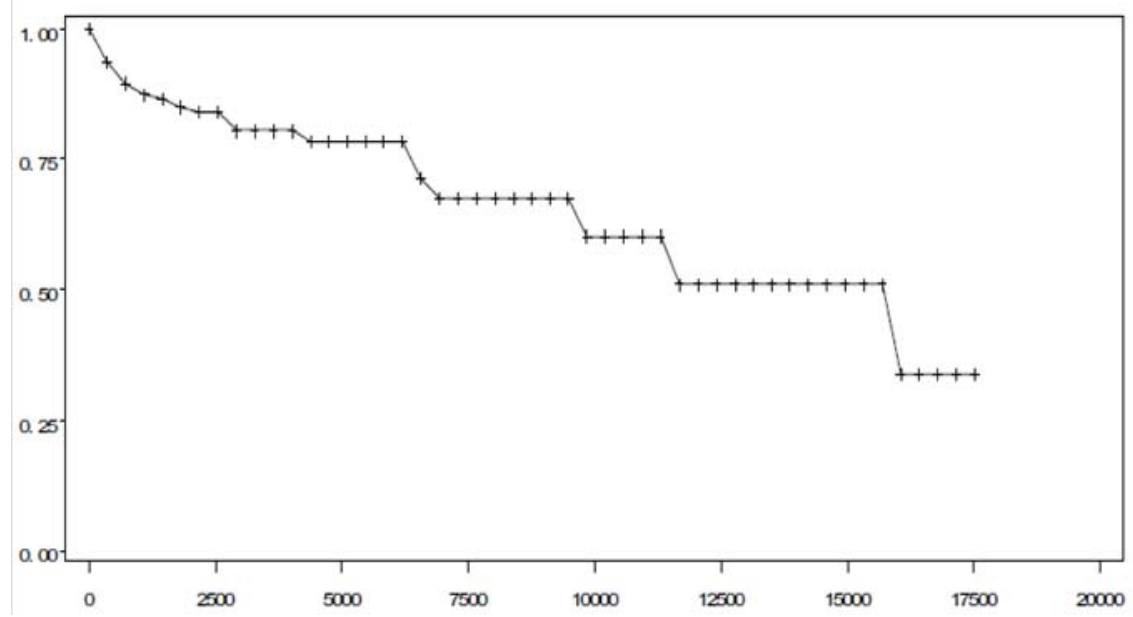

Figure 4: Survival function of conflicts ending with cease-fire.

different parameters for the first, second, and third or more spells and separate log-logistic models for different endings (peace, cease-fire, peace and cease-fire, victory for side A, victory for side B, no or low activity, and other), for cause of conflict (territory or government), for wars in the five regions, for minor and major wars, and for short and long wars (less/more than 1 year). We are interested in the outbreak of peace. The basic observation is a conflict year.

Because of its size, Table A1 is placed in Appendix B. It reports the parameter 
estimates for the semiparametric Cox-type proportional hazard model and for the parametric log-logistic model of conflict termination. Unobserved heterogeneity, or frailty, is not statistically significant. Therefore, the models which are reported in Table A1 are without unobserved heterogeneity parameter estimates.

The parameter of having an incompatibility because of governmental issues is only significantly estimated in the Cox-type proportional hazard model. The termination risk of conflict increases when it includes a governmental issue during the first spell but decreases during the second and third or more spells. The chances of conflict termination are higher during the first conflict spell when third parties are involved. If war has not ended during the first spell then the termination chances are becoming lower for repeated conflict spells.

Regardless of the conflict outcome, conflicts have longer spells in regions other than Europe. From shortest to the longest, conflict spells are distributed among the regions as follows: Europe, Africa, the Americas, the Middle East, and Asia.

The intensity of war is important: Major wars are more likely to end with peace or cease-fire agreements than do minor wars, and termination chances are higher for long wars. But interstate conflict lowers termination chances for low-activity wars or if these wars are in Africa or they are of a governmental incompatibility character. This means that major wars, for any reason, end faster than minor ones. This also means that we observe shorter spells if war costs more lives. Put differently, termination risks are lowered if conflicts are showing low or no activity. Conflicts between states terminate more quickly than internal wars.

\section{Conclusions}

Based on UCDP data for 1946 to 2007, we find that conflicts are shorter in Europe, followed in increasing length by Africa, the Americas, the Middle East, and Asia. Major conflicts terminate more quickly than do minor ones, except where they terminate because of low activity (which is to be expected). Conflicts between states terminate more quickly than internal wars. Holding conflict size constant, civil wars have longer spells than wars between states. The unobserved heterogeneity parameter is not statistically significant. The models estimated with the Cox-type proportional hazard model or the log-logistic model assumptions without controlling for unobserved heterogeneity fit the UCDP dataset well.

\section{Notes}

Ron Smith is Professor of Economics at Birkbeck College, University of London. Ali Tasiran, the corresponding author, is Professor of Economics at Birkbeck College, University of London, and Senior Lecturer, Statistics, Middlesex University, London, and may be reached at<atasiran@ems.bbk.ac.uk>.
1. Anderton and Carter (2011).

2. Many: See, e.g., Barrringer (1972), Hough (1964), Pruitt and Synder (1969), and Sambanis (2004). Others: See, e.g., Collier (1999), Richardson (1960), Russe (1972), Seaty (1968), Small and Singer (1982), and Wright (1942; 1965).

3. Cramer (2006).

4. Richardson (1948; 1960).

5. Exception: See GBAV (2008; 2011). Also see Brauer and Dunne (2011).

6. Harbom and Wallensteen (2007); also see the Human Security Report 2009/10 $<$ http://www.hsrgroup.org/> [accessed 25 October 2011].

7. Interdependence and duration: e.g., Krustev (2006); transnational dimensions: e.g., Gleditsch (2007); enduring internal rivalries: e.g., DeRouen and Bercovitch (2008).

8. The quotes come from Richardson (1960).

9. Recent study: Bohorquez, et al. (2009).

10. Large literature: See, e.g., Hegre (2004), which is an introduction to a special issue of the Journal of Peace Research on the duration and termination of war.

11. Bleaney and Dimico (2011).

12. The number of 17,500 days (almost 50 years) on the horizontal axis of Figure 2 is the total length of the longest first spell between Israel and Palestine. It is one of the 235 spells observed as first conflicts in Table 2.

\section{References}

Anderton, C.H and J.R. Carter. 2011. "Conflict Datasets: A Primer for Academics, Policymakers and Practitioners.” Defence and Peace Economics. Vol. 22, No. 1, pp. 21-42.

Barrringer, R.E 1972. War: Patterns of Conflict. Cambridge, MA: MIT Press.

Bleaney, M. and A. Dimico. 2011. "How Different are the Correlates of Onset and Continuation of Civil Wars?” Journal of Peace Research. Vol. 48, No. 2, pp. 145-155.

Bohorquez, J.C., S. Gourley, A.R. Dixon, M. Spagat, and N.F. Johnson. 2009. “Common Ecology Quantifies Human Insurgency.” Nature. Vol. 462, p. 911. 
Brauer, J. and J.P. Dunne. 2011. “Macroeconomics and Violence,” pp. 311-337 in D. Braddon and K. Hartley, eds. Handbook on the Economics of Conflict. Cheltenham, UK: Elgar.

Collier, P. 1999. “On the Economic Consequences of Civil War.” Oxford Economic Papers. Vol. 51, pp. 168-183.

Cox, D. 1972. “Regression Models and Life Tables.” Journal of the Royal Statistical Society (Series B). Vol. 34, pp. 187-220.

Cramer, C. 2006. Civil War is Not a Stupid Thing: Accounting for Violence in Developing Countries. London: Hurst.

DeRouen K.R., Jr., and J. Bercovitch. 2008. "Enduring Internal Rivalries: A New Framework for the Study of Civil War.” Journal of Peace Research. Vol 45, No 1, pp. 55-74.

Gleditsch, K.S. 2007. “Transnational Dimensions of Civil War.” Journal of Peace Research. Vol 44, No 3, pp. 293-309.

[GBAV] Geneva Declaration on Armed Violence and Development. 2011. Global Burden of Armed Violence. Cambridge, UK: Cambridge University Press. [ $1^{\text {st }}$ ed.: 2008.]

Harbom, L. and P. Wallensteen. 2007. “Armed Conflict, 1989-2006.” Journal of Peace Research. Vol 44, No 5, pp. 623-634.

Hegre, H. 2004. "The Duration and Termination of Civil War.” Journal of Peace Research. Vol. 41, No. 3, pp. 243-252.

Hough, R. 1964. Dreadnought: A History of the Modern Battleship. London: Allen and Unwin.

Krustev, V.L. 2006. "Interdependence and the Duration of Militarized Conflict.” Journal of Peace Research. Vol 43, No 3, pp. 243-260.

Pruitt, D.G and R.C. Synder. 1969. Theory and Research on the Causes of War. Englewood Cliffs, NJ: Prentice Hall.

Richardson, L.F. 1948. "Variation of the Frequency of Fatal Quarrels with Magnitude.” Journal of the American Statistical Association. Vol. 43, No. 244, pp. 523-46.

Richardson, L.F. 1960. Statistics of Deadly Quarrels. Pittsburgh, PA: Boxwood Press.

Russe, H.B., ed. 1972. Peace, War, and Numbers. Beverly Hills, CA: Sage.

Sambanis, N. 2004. "What is a Civil War? Conceptual and Empirical Complexities of an Operational Definition.” Journal of Conflict Resolution. Vol. 48, No. 6, pp. 814-858.

Seaty, T.L. 1968. Mathematical Models of Arms Control and Disarmament: Application of Mathematical Structures in Politics. New York: Wiley.

Small, M. and J.D. Singer. 1982. Resort to Arms: International and Civil War, 1816-1980. Beverly Hills, CA: Sage.

Wilkinson, D. 1980. Deadly Quarrels: Lewis F. Richardson and the Statistical Study of War. Berkeley, CA: The University of California Press.

Wright, Q. 1942. A Study of War. Chicago, IL: The University of Chicago Press. [2 ${ }^{\text {nd }}$ ed. 1965.]

Appendix A: A duration model

A common model for duration specifies a hazard function of the form

(1) $\quad h(d \mid x, v)=h_{0}(d) \exp \left(\beta^{\prime} x\right) v$,

where the hazard is the risk of peace occurring at time $d$, given that war had continued to time $d$. This is defined as

(2) $\quad h(d)=f(d) / S(d)$,

where $f(d)$ is the probability density function, and

(3) $\quad S(d)=1-F(d)=1-P(D<d)$

is the survival function, that is, one minus the cumulative distribution function. The integrated hazard function $\Lambda(d)=-\log S(d)$ is also useful. The baseline hazard is $h_{0}(d)$. This shows how the hazard behaves over time, such as how it increases or decreases. The baseline hazard is shifted by $x$, a vector of covariates, such as external intervention, and $v$, unobserved heterogeneity. We can then examine things like the expected time before the onset of peace $\mathrm{E}\left(\mathrm{d}_{\mathrm{it}} \mid \mathrm{x}_{\mathrm{i}, \mathrm{t}-1} *\right)$ where $\mathrm{x}_{\mathrm{i}, \mathrm{t}-1} *$ contains the information in $\mathrm{x}_{\mathrm{it}-1}$ plus the source of the current conflict $\mathrm{x}_{\mathrm{i}, \mathrm{f}}$. Some wars, which have survived $d$ periods, may not have ended during the data period and these are described as censored observations. We know that a war lasted at least $d$ periods, but not when it ended.

Parametric versions of the model can be written as

(4) $\quad h(d \mid x, v, \theta)=h_{0}(d, \alpha) \exp \left(\beta^{\prime} x\right) v(\gamma)$,

where $\theta=(\alpha, \beta, \gamma)$ is the full set of parameters, from baseline hazard, covariates, and unobserved heterogeneity. Parametric models are usually estimated by maximum likelihood, where the log likelihood takes the form of

(5) $\log L(\theta)=\Sigma_{U} \log f(d, \theta)+\Sigma_{C} \log S(d, \theta)=\Sigma_{U} \log h(d, \theta)+\Sigma_{A} \log S(d, \theta)$.

The sums are taken over uncensored observations (U), censored observations (C), and all observations (A). The censored observations thus only appear in the survival function.

An alternative was proposed by Cox (1972) and subsequently discussed by many other authors. For the single transition case, and based on a continuous time variable, 
t, the model, generally called a Cox-type proportional hazard model is

(6) $\quad h(d \mid X, v)=h_{0}(d) \exp \left(\beta^{\prime} X(t)\right) v(\gamma)$.

The transition rate, $h(d \mid X, v)$, depends on an unspecified baseline rate, $h_{0}(d)$, and on a vector of covariates, $X(t)$, with coefficients $\beta$ '. The covariates may vary over time, $t$.

As an example of a parametric model, the log-logistic model assumes that the baseline hazard follows a log-logistic distribution. The density, survivor, and rate functions for this distribution are:

(7) $\quad f(t)=\left[b a^{b} t^{b-1}\right] /\left[1+(a t)^{b}\right]^{2}$, with $a, b>0$

(8) $\mathrm{S}(\mathrm{t})=1 /\left[1+(\mathrm{at})^{\mathrm{b}}\right]$

(9) $\mathrm{h}(\mathrm{t})=\left[\mathrm{b} \mathrm{a}^{\mathrm{b}} \mathrm{t}^{\mathrm{b}-1}\right] /\left[1+(\mathrm{at})^{\mathrm{b}}\right]$.

The rate reaches its maximum $h_{\max }$, given by $h_{\max }=a(b-1)^{1-1 / b}$, time $t_{\max }$, given by $t_{\max }=(1 / a)(b-1)^{1 / b}$. Starting values for estimating the standard log-logistic model are not critical, and in most situations it is sufficient to set the shape parameter $b=1$ and to use for the parameter $a$ the constant rate of an accordingly defined exponential null model. 
(c) www.epsjournal.org.uk - Vol. 7, No. 1 (2012)

\section{Appendix B}

\section{Table A1: Estimated parameters in Cox-type proportional hazard and log-logistic models of conflict termination}

\begin{tabular}{|c|c|c|c|c|c|c|c|c|c|c|c|c|}
\hline \multirow[t]{2}{*}{ Variables } & \multicolumn{3}{|c|}{ Cox-type proportional hazard model } & \multicolumn{8}{|c|}{ Log-logistic models } & \multirow{12}{*}{ (See Table note) } \\
\hline & Spell 1 & Spell 2 & $\begin{array}{l}\text { Spell } 3 \\
\text { or more }\end{array}$ & $\begin{array}{l}\text { All } \\
\text { spells }\end{array}$ & $\begin{array}{l}\text { Peace or } \\
\text { cease-fire }\end{array}$ & Victory & $\begin{array}{l}\text { No or low } \\
\text { activity }\end{array}$ & $\begin{array}{l}\text { Govern- } \\
\text { ment }\end{array}$ & Long & Major & Internal & \\
\hline Constant A & 0 & 0 & 0 & $\begin{array}{l}-8.50[0] \\
(1.69)\end{array}$ & $\begin{array}{l}-9.55[0] \\
(1.92)\end{array}$ & $\begin{array}{l}-17.73[0] \\
(2.55)\end{array}$ & $\begin{array}{l}-12.67[0] \\
(1.23)\end{array}$ & $\begin{array}{l}-3.36 \\
(3.67)\end{array}$ & $\begin{array}{l}-7.39[0] \\
(1.00)\end{array}$ & $\begin{array}{l}-8.140[0] \\
(0.61)\end{array}$ & $\begin{array}{l}-8.579[0] \\
(2.96)\end{array}$ & \\
\hline In_Government & $\begin{array}{l}8.14 \\
(47.87)\end{array}$ & $\begin{array}{l}-0.42 \\
(0.75)\end{array}$ & $\begin{array}{l}-0.47 \\
(0.74)\end{array}$ & $\begin{array}{l}-0.50 \\
(1.51)\end{array}$ & $\begin{array}{l}-1.28 \\
(1.63)\end{array}$ & 0 & 0 & 0 & $\begin{array}{l}-1.41 \\
(0.88)\end{array}$ & 0 & $\begin{array}{l}-0.52 \\
(2.89)\end{array}$ & \\
\hline R_Middle East & $\begin{array}{l}-0.55 \\
(0.38)\end{array}$ & $\begin{array}{l}-1.60[0] \\
(0.39)\end{array}$ & $\begin{array}{l}-0.62[9] \\
(0.37)\end{array}$ & $\begin{array}{l}-2.71[0] \\
(0.59)\end{array}$ & $\begin{array}{l}-3.150[0] \\
(0.82)\end{array}$ & $\begin{array}{l}-3.13[7] \\
(1.72)\end{array}$ & $\begin{array}{l}-1.37[5] \\
(0.69)\end{array}$ & $\begin{array}{l}-3.07[3] \\
(1.41)\end{array}$ & $\begin{array}{l}-1.60[0] \\
(0.42)\end{array}$ & $\begin{array}{l}-0.37 \\
(0.76)\end{array}$ & $\begin{array}{l}-3.31[0] \\
(0.70)\end{array}$ & \\
\hline R_Asia & $\begin{array}{l}-1.70[0] \\
(0.37)\end{array}$ & $\begin{array}{l}-2.38[0] \\
(0.34)\end{array}$ & $\begin{array}{l}-0.90[1] \\
(0.33)\end{array}$ & $\begin{array}{l}-4.34[0] \\
(0.54)\end{array}$ & $\begin{array}{l}-4.91[0] \\
(0.74)\end{array}$ & $\begin{array}{l}-7.69[0] \\
(1.71)\end{array}$ & $\begin{array}{l}-2.08[0] \\
(0.63)\end{array}$ & $\begin{array}{l}-6.83[0] \\
(1.36)\end{array}$ & $\begin{array}{l}-2.20[0] \\
(0.37)\end{array}$ & $\begin{array}{l}-3.09[0] \\
(0.67)\end{array}$ & $\begin{array}{l}-4.53[0] \\
(0.62)\end{array}$ & \\
\hline R_Africa & $\begin{array}{l}-0.49 \\
(0.34)\end{array}$ & $\begin{array}{l}-1.18[0] \\
(0.31)\end{array}$ & $\begin{array}{l}-0.41 \\
(0.34)\end{array}$ & $\begin{array}{l}-2.12[0] \\
(0.53)\end{array}$ & $\begin{array}{l}-2.68[0] \\
(0.67)\end{array}$ & $\begin{array}{l}-2.15 \\
(1.53)\end{array}$ & $\begin{array}{l}-0.98 \\
(0.64)\end{array}$ & $\begin{array}{l}-9.46[0] \\
(0.51)\end{array}$ & $\begin{array}{l}-1.45[0] \\
(0.37)\end{array}$ & $\begin{array}{l}-3.11[0] \\
(0.69)\end{array}$ & $\begin{array}{l}-2.29[0] \\
(0.61)\end{array}$ & \\
\hline R_Americas & $\begin{array}{l}0.38 \\
(0.36)\end{array}$ & $\begin{array}{l}-1.52[0] \\
(0.43)\end{array}$ & $\begin{array}{l}-1.99[0] \\
(0.59)\end{array}$ & $\begin{array}{l}-2.21[0] \\
(0.63)\end{array}$ & $\begin{array}{l}-3.22[0] \\
(0.88)\end{array}$ & $\begin{array}{l}1.11 \\
(1.63)\end{array}$ & $\begin{array}{l}-4.03[0] \\
(1.07)\end{array}$ & $\begin{array}{l}-5.42[0] \\
(1.36)\end{array}$ & $\begin{array}{l}-2.92[0] \\
(0.55)\end{array}$ & $\begin{array}{l}-2.27[1] \\
(0.88)\end{array}$ & $\begin{array}{l}-2.78[0] \\
(0.73)\end{array}$ & \\
\hline Int_Major & $\begin{array}{l}0.31 \\
(0.22)\end{array}$ & $\begin{array}{l}0.11 \\
(0.23)\end{array}$ & $\begin{array}{l}-1.22[0] \\
(0.28)\end{array}$ & $\begin{array}{l}-0.03 \\
(0.30)\end{array}$ & $\begin{array}{l}1.15[0] \\
(0.42)\end{array}$ & $\begin{array}{l}0.09 \\
(0.88)\end{array}$ & $\begin{array}{l}-1.01[1] \\
(0.37)\end{array}$ & $\begin{array}{l}-1.12[3] \\
(0.52)\end{array}$ & $\begin{array}{l}0.65[1] \\
(0.20)\end{array}$ & 0 & $\begin{array}{l}-0.25 \\
(0.36)\end{array}$ & \\
\hline T_Interstate & $\begin{array}{l}1.79[0] \\
(0.53)\end{array}$ & $\begin{array}{l}2.79[0] \\
(0.49)\end{array}$ & $\begin{array}{l}3.10[0] \\
(0.64)\end{array}$ & $\begin{array}{l}5.39[0] \\
(0.72)\end{array}$ & $\begin{array}{l}5.56[0] \\
(1.02)\end{array}$ & $\begin{array}{l}8.65[0] \\
(2.40)\end{array}$ & $\begin{array}{l}5.55[0] \\
(1.16)\end{array}$ & $\begin{array}{l}6.85[9] \\
(3.99)\end{array}$ & $\begin{array}{l}1.75[0] \\
(0.50)\end{array}$ & 0 & 0 & \\
\hline T_Internal & $\begin{array}{l}0.25 \\
(0.047)\end{array}$ & $\begin{array}{l}-0.17 \\
(0.44)\end{array}$ & $\begin{array}{l}1.18[5] \\
(0.59)\end{array}$ & $\begin{array}{l}-0.09 \\
(0.59)\end{array}$ & $\begin{array}{l}-0.53 \\
(0.86)\end{array}$ & $\begin{array}{l}1.14 \\
(2.03)\end{array}$ & $\begin{array}{l}1.72 \\
(1.05)\end{array}$ & $\begin{array}{l}-3.16 \\
(3.46)\end{array}$ & $\begin{array}{l}-0.83[2] \\
(0.35)\end{array}$ & 0 & 0 & \\
\hline $\begin{array}{l}\text { Constant B } \\
\text { (shape parameter) }\end{array}$ & 0 & 0 & 0 & $\begin{array}{l}-0.86[0] \\
(0.05)\end{array}$ & $\begin{array}{l}-0.65[0] \\
(0.09)\end{array}$ & $\begin{array}{l}-1.44[0] \\
(0.09)\end{array}$ & $\begin{array}{l}-0.55[0] \\
(0.07)\end{array}$ & $\begin{array}{l}-1.03[0] \\
(0.07)\end{array}$ & $\begin{array}{l}-0.21[0] \\
(0.06)\end{array}$ & $\begin{array}{l}-0.56[0] \\
(0.08)\end{array}$ & $\begin{array}{l}-0.95[0] \\
(0.05)\end{array}$ & \\
\hline $\begin{array}{l}\text { Neg Log-Lik } \\
\text { (without variables) }\end{array}$ & & 2726 & & 4362 & 1326 & 1494 & 1470 & 1915 & 2426 & 1411 & 3511 & \\
\hline $\begin{array}{l}\text { Neg Log-Lik } \\
\text { (with variable) }\end{array}$ & & 2584 & & 3897 & 1186 & 1164 & 1643 & 1656 & 2357 & 1346 & 3187 & \\
\hline \multicolumn{13}{|l|}{ Spells } \\
\hline 0 to 0 & & 1539 & & 1516 & 1805 & 1790 & 1768 & 637 & 1502 & 428 & 1372 & \\
\hline 0 to 1 & 122 & 107 & 79 & 396 & 107 & 122 & 144 & 175 & 207 & 129 & 313 & \\
\hline Sum & & 1912 & & 1912 & 1912 & 1912 & 1912 & 812 & 1709 & 557 & 1685 & \\
\hline
\end{tabular}

Note: The bracketed expressions show p-values of 0.1 or less of the estimated parameters. Instead of reporting the conventional significance levels at 5, 2.5, 1-percent levels, we prefer to report the calculated significance values of the estimated coefficients as p-values. Thus, for example, [5] means a p-value of 0.05 . Coefficients without bracketed expressions have p-values greater than 0.1 . 